\title{
Quantifying the Probability of a Banking Crisis and the Implications for Sovereign Risk
}

\author{
Adina-Ionela Străchinaru \\ Bucharest University of Economic Studies, Romania
}

\begin{tabular}{ll} 
ARTICLE INFO & ABSTRACT \\
\cline { 1 - 2 } $\begin{array}{l}\text { Keywords: } \\
\text { Banking Crisis }\end{array}$ & $\begin{array}{l}\text { Identify and validate tools that anticipate the influence of } \\
\text { macroeconomic indicators, whose history has indicated, at } \\
\text { Financial Stability } \\
\text { Pandemic }\end{array}$ \\
Sovereign Risk & $\begin{array}{l}\text { international level, episodes of economic collapse are the main } \\
\text { objective of the paper. Using a logistic regression, I captured a } \\
\text { model for quantifying the probability of banking crises, }\end{array}$ \\
& $\begin{array}{l}\text { integrating indicators of the scoreboard on macroeconomic } \\
\text { imbalances, as well as the sovereign risk premium for European } \\
\text { countries. In this sense, the results show the premises underlying } \\
\text { the elaboration of the analytical framework for the propagation } \\
\text { of sovereign risk at the level of credit institutions. }\end{array}$ \\
\hline
\end{tabular}

\section{Introduction}

The banking crises of last years have signaled the need for early warning systems that would provide, in a timely manner, the vulnerabilities of the macro-financial system. The financial sector generally has a positive impact on economic growth. The efficient placement of resources between those who save and who want to invest helps to implement monetary policy, which can significantly reduce fluctuations in business cycles, thus ensuring financial stability and increasing the well-being of the economy. At the same time, the financial sector can create imbalances in the economy, becoming a source of systemic risk, with contagion effects in the supply of loans - significant impact on the real economy (population and NFI).

Peculiarities of emerging economies (the case of Romania), such as inconsistencies in the mix of economic policies, the expansion of monetary substitution, labor migration, legislative uncertainty, deteriorating investor confidence, political uncertainty, the structure and cost of financing the current account deficit and of the budget deficit, the risk of non-repayment of non-government loans, contributes to the amplification of interaction between the banking sector, the public administration and the real economy channels.

The financial system has already felt the effects of the pandemic in the first wave recorded in spring 2020, and the monetary authorities have developed studies to capture ways to rehabilitate the economy. Thus, through its policies, the European Central Bank has diminished the effect of the Covid-19 contagion on the European sovereign debt markets, developing an emergency procurement program in the context of the pandemic Pandemic Emergency Purchase Programme-PEPP) (Ortmans \& Tripier, 2020).

In the context of the unfavorable evolutions on the financial markets, the financing conditions have tightened, and the curves of the sovereign returns, fundamental for establishing the quotations of the assets, registered a generalized increase. As a result, bank solvency is declining and government liabilities are rising.

\footnotetext{
* Corresponding author E-mail address: adina.strachinaru@ fin.ase.ro 
The new program comes in support of counteracting the major risks to the monetary policy transmission mechanism, targeting securities issued by the public and private sector in order to support the public debt.

Among the package of monetary policy measures is the provision of liquidity, being fundamental in periods characterized by uncertainties. Although the Governing Council $(\mathrm{ECB}, 2020)^{1}$ does not notice major tensions in money markets or episodes of illiquidity, the aim of the measure is to prevent possible price pressures, especially in the case of operational risks to participants in the financial system, a likely effect of coronavirus.

Another measure refers to the relaxation of financing conditions that supported bank lending to companies and the population, due to the negative influence exerted by the spread of the Covid-19 virus on the incomes and expenses of companies and the population. In this sense, there is a pronounced dependence between the banking sector, the government and the real economy.

Concerns in the literature refer to the impact that shocks between public finances and the financial sector have on the real economy.

The connection between sovereign risk and banks can be highlighted, especially, through three channels ${ }^{2}:$ 1) large portfolios of government securities in banks' balance sheets; 2) the role of the public administration as a financier of last resort of the bank resolution funds; 3 ) indirect effects through the real economy. Hence the importance of political implications in making a diagnosis and finding potential solutions to monitor systemic risks and, implicitly, to ensure and maintain financial stability.

Although eurozone governments are trying to close the loop between banks and sovereign risk, policy makers are still failing to reach a consensus on how to deal with the concentration of sovereign exposures in the credit risk portfolio ${ }^{3}$. A possible solution, in this sense, would be a new reform regarding different categories of risk exposures, placed in a bank.

The very high exposure of sovereign bonds in the bank balance sheet can create a major imbalance in the economy. The sovereign risk is transmitted to the banks in a reduction of the credit offer. In an article published in the Financial Times ${ }^{4}$, Dr. Jens Weidmann, president of the Deutsche Bundesbank, reminds about the importance of reducing the connection between sovereign risk and banking instability, supported by the financial crisis of sovereign debt. Avoiding the takeover of government burdens by banks becomes a necessity, given the unfavorable level of insolvency and liquidity, reflected in the bank balance sheet.

The topic refers to the connection between the state, which issues government bonds to cover its budget deficit and the banks, which take over the burden of the state debt. Although at high exposures, the impact on the bank balance sheet may be greater by affecting bank solvency, the reasons why banks resort to government bonds are related to the attractiveness of the liquidity-profitability ratio, given that government securities are assets eligible for refinancing credit institutions. at the central bank. Moreover, the regulations on minimum capital requirements for exposures arising from government bonds provide for a very low degree of risk (even zero in the case of debt denominated in national currency).

\footnotetext{
${ }^{1}$ ECB, Economic Bulletin no 2/2020

${ }^{2}$ Managing the sovereign-bank nexus, ECB, No 2177 / September 2018

${ }^{3}$ Regulating the doom loop, ECB, No 2313 / September 2019

4 "Stop encouraging banks to load un on state debt", published on 1 October 2013 in Financial Times, Dr. Jens Weidmann, president of the Deutsche Bundesbank
} 
During the crisis, the share of sovereign bonds in total banking assets increased, according to Deutsche Bundesbank studies, published in the BIS $(2013)^{1}$. Therefore, the more vulnerable banks are, the more they are exposed to sovereign debt. Vulnerable banks usually invest in high-yield bonds, refinancing at a lower interest rate. This encourages low bank profitability and a delay in business model adjustments.

Also, in an economy in which the sovereign fails, the probability that the banks will follow the same trajectory is very high. Hence the strong connection between these two key components of the economy.

As a solution, the monetary authorities recommend that banks no longer overburden the state's debts, although the regulations in force indirectly support this. Moreover, the European Banking Union can be a remedy in order to reduce the risk contagion between them, in the light of the revision of the regulations, regarding the minimum capital requirements of the banks compared to the sovereign exposures.

Banks with high exposure to European sovereign debt have reduced their lending to the private sector. This is contrary to market rules, so a high market interest rate no longer reflects the degree of risk of an investment. The fear, manifested both by banks and by the state, that of increasing financing costs, which can generate chaos in the economy, increases with the intention of the monetary authorities to change the minimum capital requirements to preferential exposures. However, the degree of risk depends on the price level of a bond, which is why regulatory adjustments should not be an issue for investors ${ }^{2}$ (ESRB, 2015). When it comes to financing government spending, a healthy banking system with a welldiversified portfolio will take on a smaller state debt burden. The fewer government liabilities, the lower the risk of investments in government bonds and, implicitly, their return.

Normally, there are multiple responses of prudential policy makers to mitigate the risks arising from the sovereign risk-banking instability connection, but many of them are not feasible without a European regulatory framework. The application of prudential requirements higher than zero, regarding the exposure to sovereign risk by banks can be a solution for the case of Romania as well. This would reduce the connection / dependence between sovereign risk and banking instability, but would favor unwanted procyclicality (MFI, 2019) ${ }^{3}$ by increasing capital requirements in times of crisis and, implicitly, reducing sovereign debt and / or decreasing the credit supply (Véron, 2017) ${ }^{4}$. Lending is also closely linked to House Prices at Risk, which has a major impact on financial stability.

Reviewing liquidity requirements in prudential regulations could also be a solution in reducing sovereign exposures from banks. In other words, reconsidering the need to hold national sovereign bonds to meet liquidity requirements may be part of the solution. This measure cannot be unique because, in most cases, banks fail to provide additional capital to absorb losses during sovereign crises, which could damage lending and thus reduce the ability to safeguard the financial system through adequacy liquidity. An additional solution is represented by macroprudential policies, through which capital supplements for systemic risk can be requested.

\footnotetext{
${ }^{1}$ Bank for International Settlements, 2013

${ }^{2}$ ESRB report on the regulatory treatment of sovereign exposures, March 2015

3 Vulnerabilities in a Maturing Credit Cycle, Global Financial Stability Report (apr 2019), International Monetary Fund

${ }^{4}$ Nicolas Véron (2017). Sovereign Concentration Charges: A New Regime for Banks' Sovereign Exposures. Bruegel \& Peterson Institute for International Economics, November 2017

https://bruegel.org/wp-content/uploads/2017/11/IPOL_STU2017602111_EN.pdf
} 
Consequently, recent experience has shown that government bonds are risky and that regulations on capital requirements for banks' exposure to sovereign risk should be revised to break or at least diminish the connection between sovereign risk and banking instability.

\section{Materials and Methods}

The research is based on two parts: macroeconomic indicators that define banking stability, proposed by the European Commission (history and explanation), based on which a score function is obtained, captured by a binary dummy variable and quantifying the impact of the banking crisis on sovereign risk, expressed with the help of the risk premium, respectively the CDS 5 Y quotation.

In this regard, a number of indicators on macroeconomic imbalances have been used as early warning factors in order to anticipate banking crises.

The instrument used, respectively, the logistic regression indicates the model efficiency in order to reflect the influence of the macro indicators on the probability prediction and, subsequently, the testing the sovereign risk premium relevance.

In this sense, there is a close link between the sovereign and the stability of the banking system, connection, located on the front page of the agenda of policy makers, due to major implications on the trajectories in both directions of the triangle: banking, public administration and real economy.

The importance of the topic is found in the vulnerability of the banking sector opposite to sovereign risk, which is, moreover, a factor of systemic importance for the economy. The aim of the study is to capture the dependence of banking stability on sovereign risk, in terms of indicators early warning.

Quantifying the dependence of banking stability on sovereign risk can be captured by a set of indicators of high statistical quality, on macroeconomic imbalances, proposed by the European Commission's scoreboard. The 14 indicators cover the major sources of macroeconomic imbalances, competitiveness and adjustment issues, such as:

- 3-year backward moving average of the current account balance as percent of GDP, with thresholds of $+6 \%$ and $-4 \%$ (ca);

- net international investment position as percent of GDP, with a threshold of -35\% (ni);

- 5-year percentage change of export market shares measured in values, with a threshold of $-6 \%$ (re);

- 3-year percentage change in nominal unit labour cost, with thresholds of $+9 \%$ for euro area countries and $+12 \%$ for non-euro area countries (em);

- 3-year percentage change of the real effective exchange rates based on HICP/CPI deflators, relative to 41 other industrial countries, with thresholds of $-/+5 \%$ for euro area countries and $-/+11 \%$ for non-euro area countries (lc);

- private sector debt (consolidated) in \% of GDP with a threshold of $133 \%$ (dc);

- private sector credit flow in \% of GDP with a threshold of $14 \%$ (cf);

- year-on-year changes in house prices relative to a Eurostat consumption deflator, with a threshold of 6\% (hp);

- general government sector debt in \% of GDP with a threshold of $60 \%$ (gd);

- 3-year backward moving average of unemployment rate, with a threshold of $10 \%$ (un);

- year-on-year changes in total financial sector liabilities, with a threshold of $16.5 \%$ (fl);

- 3-year change in p.p. of the activity rate, with a threshold of $-0.2 \%$ (ar);

- 3-year change in p.p. of the long-term unemployment rate, with a threshold of $+0.5 \%$ (ua);

- 3-year change in p.p. of the youth unemployment rate, with a threshold of $+2 \%$ (yu). 
The methodological framework involves the use of logistic regression on a series of panel data for European Union countries in order to determine the probability of banking crises. The importance of the study will be given by testing the relevance of the sovereign risk premium, expressed by the CDS $5 \mathrm{Y}$ rating. In order to make estimates, we used the R Studio software for data series with annual frequency, for a period of 15 years (2005-2019), using two types of variables: quantitative, used as early warning indicators, respectively, qualitative, dummy type, which surprise the probability of banking crises ( 1 for the existence of crisis periods, 0 otherwise).

\section{Results}

The 14 indicators of the scoreboard on macroeconomic imbalances, proposed by the European Commission ${ }^{1}$, were taken into account as exogenous quantitative variables. A brief description of the data is presented in the following table (Table 1):

Table 1.

Descriptive Statistics

\begin{tabular}{ccccc}
\hline & Mean Diff. & eQQ Med & eQQ Mean & eQQ Max \\
\hline distance & 91.6145 & 81.6152 & 77.3373 & 72.2535 \\
\hline ca & 20.0294 & 30.7692 & 15.4076 & -6.5217 \\
ni & 93.4424 & 50.0000 & 56.1687 & 42.6716 \\
re & 68.6186 & 68.7500 & 42.6233 & -118.5185 \\
em & 81.4122 & 61.8609 & 60.4938 & 9.1115 \\
lc & 6.2422 & -85.7143 & -5.9725 & -146.9880 \\
hp & 98.4907 & 80.0000 & 73.8235 & 12.2951 \\
cf & 96.5729 & 60.7143 & 57.2751 & 78.4705 \\
dc & 83.3550 & 75.9227 & 74.0046 & 66.7355 \\
gd & 91.1283 & 77.3148 & 72.6090 & 38.1636 \\
un & 100.0000 & 50.0000 & 55.9724 & 20.0000 \\
fl & 91.8990 & 68.5714 & 60.3969 & 37.1795 \\
ar & 62.3843 & 42.8571 & 47.5115 & 22.7273 \\
ua & 95.9870 & 85.7143 & 81.3031 & 48.5294 \\
yu & 99.3419 & 87.5000 & 85.2292 & 57.0423 \\
\hline
\end{tabular}

Source: Own Calculations, Using R Studio

Modeling the crisis probability, qualitative variable, dummy type, I used the database established by the European System of Central Banks (ESCB) and the European Systemic Risk Board (ESRB) (Alessi, 2014; Ferrari, 2015; Lo Duca, 2017; Lang, 2018; Laeven, 2018), based on which I structured the binary dependency variable for EU countries, identifying the periods considered problematic for banking stability.

After estimating the data, I obtained the following results, according to the table below (Table 2) $\ln \left(\frac{\hat{p}}{1-\hat{p}}\right)=-4.3820+5.9134 \mathrm{ca}-0.5920 \mathrm{ni}-0.5296 \mathrm{re}+\ldots-2.9912 \mathrm{yu}$

\footnotetext{
${ }^{1}$ European Commission: https://ec.europa.eu/info/business-economy-euro/economic-and-fiscal-policycoordination/eu-economic-governance-monitoring-prevention-correction/macroeconomic-imbalanceprocedure/scoreboard_en
} 
Table 2.

Logit Regression Coefficients

\begin{tabular}{ccccc}
\hline & Estimate & Std. Error & $\mathrm{z}$ value & $\operatorname{Pr}(>|\mathrm{z}|)$ \\
\hline Intercept & -4.3820 & 0.7456 & -5.8770 & $4.17 \mathrm{e}-09^{* * *}$ \\
ca & 5.9134 & 4.2826 & 1.3810 & 0.1673 \\
ni & -0.5920 & 0.4095 & -1.4460 & 0.1482 \\
re & -0.5296 & 2.9431 & -0.1800 & 0.8572 \\
em & 0.7999 & 0.8853 & 0.9040 & 0.3662 \\
lc & 6.4013 & 2.2526 & 2.8420 & $0.00449^{* *}$ \\
hp & -11.3953 & 3.0745 & -3.7060 & $0.00021^{* * *}$ \\
cf & -1.1034 & 1.5205 & -0.7260 & 0.4680 \\
dc & 1.1584 & 0.2354 & 4.9210 & $8.62 \mathrm{e}-07^{* * *}$ \\
gd & 2.3239 & 0.5667 & 4.1010 & $4.12 \mathrm{e}-05^{* * *}$ \\
un & -2.5109 & 5.3516 & -0.4690 & 0.6389 \\
fl & -1.5129 & 1.9043 & -0.7940 & 0.4269 \\
ar & -27.6568 & 12.8506 & -2.1520 & $0.03138^{*}$ \\
ua & 32.2269 & 16.3617 & 1.9700 & $0.04888^{*}$ \\
yu & -2.9912 & 4.6147 & -0.6480 & 0.5169
\end{tabular}

Note: $* * *, * *$ and $*$ indicates a significance threshold of $0 \%, 0,1 \%$ and $1 \%$

Source: Own Calculations, Using R Studio

Estimated results indicate that for each unit of growth of the "ca" indicator, for example, In [p/1-p)] increases by 5.9134 units. Given that $\ln [\mathrm{p} /(1-\mathrm{p})]$ is $\log$ and not probability, we will interpret only the sign, not the size of the coefficients in the logit model.

\section{Discussion}

The coefficients of the regression model indicate the vulnerabilities of the banking sector, transmitted through different channels. On the channel of external and global imbalances, the current account (ca), the export market share (\% of world exports) (em) has a positive influence on the probability of issuing early warning signals.

Regarding the macroeconomic environment, both the cost of labor (lc) and the unemployment rate (long-term) (ua) determine, in the same sense, the appearance of banking crises. Therefore, there is a direct relationship between debtors, who become insolvent, due to rising unemployment, and the bankruptcy of banks that fail to properly manage bank assets and liabilities.

On the other hand, the average duration, respectively 3 years for the unemployment rate (un), the age of the population, ie the youth unemployment rate (yu), but also the active rate (ar) of the total population recorded modifications in the opposite direction, given the period relatively low in order to emit early warning signals.

On the credit channel, the debt of the public administration sector (gd), but also the private sector debt (dc), are triggering factors of the banking crises, especially, by extending the sovereign risk. In other words, there is a relationship of dependence between the government, which issues government bonds to finance itself, and the banking sector, which is too burdened with state debt due to the attractiveness and stability of government securities.

On the other hand, net investment (ni), real exchange rate (re), house price index (hp), private sector credit flow (cf), unemployment rate (un), financial sector debt (fl), rate activity rate (ar) and youth unemployment rate (yu) have a negative effect on the probability of banking crises, inversely influencing the evolution of the dependent variable.

Throughout history, banking crises have been preceded by an asset price boom (Beutel et al, 2018). On the channel of the price of financial assets, house price index (hp) reveals a significant influence on the onset of banking crises. However, the housing price boom can be 
observed not only during the financial crisis of 2008, but also in emerging countries, such as Finland, Sweden, Spain (Reinhart and Rogoff, 2008).

The net investment position (ni) indicates that liabilities exceed external financial assets, so that the burden of government debt extends to both the domestic banking sector for the sample countries and the foreign one. This fact is also underlined by the net amount of liabilities (cf), but also by the one at the level of the entire financial sector (fl) represented by currency, deposits, debt securities, loans, equity and investment fund shares and so on. ${ }^{1}$

The real exchange rate (re) indicates the cost of a country's competitiveness related to its competitors on international markets, but the oscillations of the indicator (here the negative sign) depend not only on costs, but also on price trends.

Table 3.

Indicators with Discrimination Power

\begin{tabular}{cc}
\hline auc_d & 0.866054 \\
gini & 0.732107 \\
ks & 0.603177 \\
\hline
\end{tabular}

Source: Own Calculations, Using R Studio

The efficiency of the logit regression model is shown in Graph 1, as well as by the values of the indicators auc_d, gini, respectively ks, which indicate a strong power of discrimination of the variables used (Table 3 ).

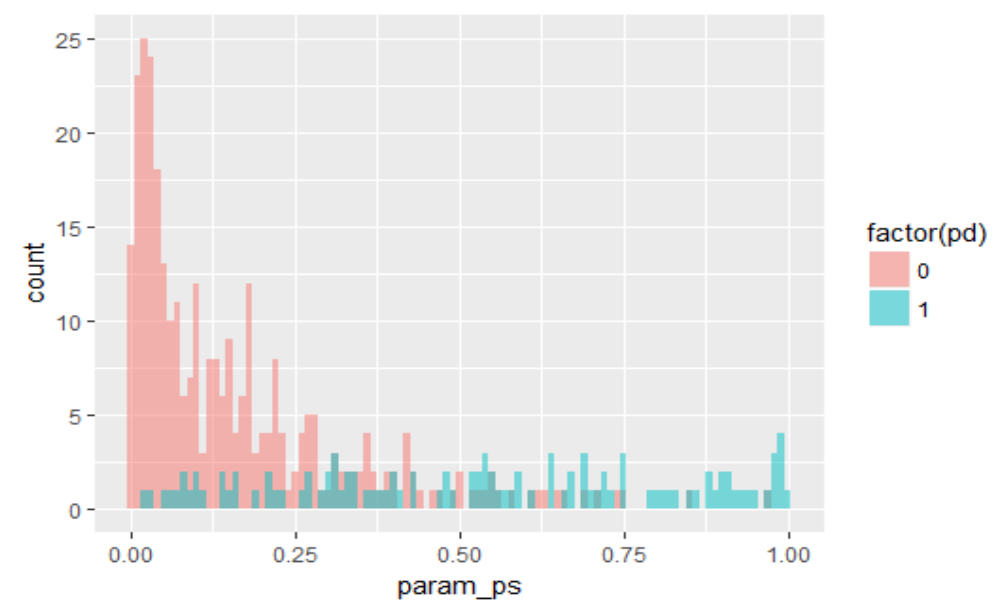

Graph 1. Probability of Default

Source: Own Calculations, Using R Studio

Consequently, the estimated results aim at obtaining a model for quantifying the probability of banking crises, which integrates information on the situation of public finances and its consequences in terms of external balance.

\section{Conclusions}

The study enjoys topicality and complexity among economic policies. The results aim at possible solutions in order to diminish or break the connection between these two crucial risks, with a systemic impact on the economy.

The estimates emphasize the importance of maintaining balance and, implicitly, stability at national and international level, reducing tensions with the foreign market with an impact on

\footnotetext{
1 European Commission: https://ec.europa.eu/info/business-economy-euro/economic-and-fiscal-policy-coordination/eu-
} economic-governance-monitoring-prevention-correction/macroeconomic-imbalance-procedure/scoreboard_en 
the sovereign risk of Romania, from neighboring countries with which we have trade relations, but also on global financial stability.

From the perspective of banking stability, credit risk remains the major concern with a significant impact on the probability of banking crises and from this point of view we understand the important role of economic agents' expectations in the functioning of the economy and in the elaboration of macroeconomic policies.

The present research does not exhaust, in any way, the indicators that manage to issue warning signals regarding the crises, as it is necessary to take into account qualitative factors. Thus, rumors accompanied by assessments without a real basis self-fulfilling profecies, which are self-sustaining on the market, can cause loss of credibility and even bankruptcy of the bank. In the literature, the notion of self-fulfilling profecy shows that what is anticipated in the market is what will happen, even if there are no other economic foundations to justify the ability of a bank to honor its payments, for example.

Thus, as the financial market evolves in the context of the new epidemiological framework, and financial products become more complex, the risks facing the banking sector will increase significantly, and their management process will become increasingly difficult. A financial system is considered stable and if it has the capacity to allocate resources efficiently, and the risk is quantified and managed correctly by the participants; hence the government should adopt a more active attitude in increasing the financial culture of the population.

The research can be extended, using a score function, by studying the impact of the probability of the financial crisis on other macroeconomic variables determining financial instability, such as: taxation rate, exchange rate evolution, interest rate dynamics etc.

\section{References}

Alessi, Lucia; Detken, Carsten (2014). Identifing excessive credit growth and leverage. Working Paper Series, No. 1723, August 2014.

Bank for International Settlements, 2013.

Beutel, J. et al. (2018). An evaluation of early warning models for systemic banking crises: Does machine learning improve predictions?. Discussion Paper, No 48/2018

ESRB report on the regulatory treatment of sovereign exposures, March 2015.

European Commission: https://ec.europa.eu/info/business-economy-euro/economic-andfiscal-policy-coordination/eu-economic-governance-monitoring-preventioncorrection/macroeconomic-imbalance-procedure/scoreboard_en.

Ferrari, Stijn; Pirovano, Mara; Cornacchia (2015). Identifying early warning indicators for real estate-related banking crises. Occasional Paper Series, No. 8, August 2015

Financial Times "Stop encouraging banks to load un on state debt", published on 1 October 2013 in Financial Times, Dr. Jens Weidmann, president of the Deutsche Bundesbank.

https://bruegel.org/wp-content/uploads/2017/11/IPOL_STU2017602111_EN.pdf.

Laeven, Luc; Valencia, Fabian (2018). Systemic Banking Crises Revisited. IMF Working Paper, WP/18/206.

Lang, Jan Hannes; Peltonen, Tuomas A.; Sarlin, Peter (2018). A framework for earlywarning modeling with an application to banks. Working Paper Series, No 2182, October 2018.

Lo Duca, Marco et all (2017). A new database for financial crises in European countries. ECB/ESRB EU crises database. Occasional Paper Series, No. 194, July 2017. 
Managing the sovereign-bank nexus, ECB, No 2177 / September 2018.

Nicolas Véron (2017). Sovereign Concentration Charges: A New Regime for Banks' Sovereign Exposures. Bruegel \& Peterson Institute for International Economics, November 2017.

Ortmans, A. \& Tripier, F. (2020). COVID-Induced Sovereign Risk in the Euro Area: When din the ECB stop de contagion? Research and Expertise on the World Economy (Centre d`Etudes Prospectives et d'Informations Internationales - CEPII) working paper, no 202011 , october.

Regulating the doom loop, ECB, No 2313 / September 2019

Reinhart, C. M.; Rogoff, K. S. (2008). Is the 2007 US Sub-Prime Financial Crises So Different? An International Historical Comparison. The American Economic Review 98(2).

Vulnerabilities in a Maturing Credit Cycle, Global Financial Stability Report (april 2019), International Monetary Fund. 